\title{
ON SOME ASPECTS OF THE EXAMINATION IN ECONOMETRICS
}

\author{
SYMON SERBENYUK
}

Abstract. Teaching econometrics has been studied by a number of researchers, however, there is little information available on the quality of examination and on simplification of tests for demonstration the high-quality knowledge by students in concrete topics of econometrics or mathematical economics.

One can note the following main goals of studying the basics of mathematical economics or econometrics by students: forming the notions of mathematical model and of modeling economic processes and phenomena; understanding a role of using mathematical models for economics research and obtaining scientific results; formatting skills for constructing mathematical models in economics, for solving economics problems by mathematical modeling.

The main goal of this paper is to simplify test tasks, is to help to students to demonstrate the high-quality knowledge in certain areas of mathematical economics, and also is to construct a system of testing tasks, in which the emphasis was placed on the knowledge and understanding of an algorithm of solving the problem.

In the present paper, to quality examine the student knowledge in the basics of mathematical economics, a certain system of tests was constructed and is considered. The main attention is also given to algorithms and techniques of solving some tasks (problems) of mathematical economics. The following topics of mathematical economics are viewed: constructing mathematical models of linear programming, the input-output model, the Monge-Kantorovich transportation problem, the simplex method of linear programming, the graphic method of linear and nonlinear programming, the method of Lagrange multipliers in mathematical optimization. Some primary basic results of studying linear programming, nonlinear programming, and the input-output model are noted.

A new system of tests that satisfies the aim of this paper is modeled. The described tests require less time for solving than usual tasks. Here we do not focus on the repetition of auxiliary mathematical knowledge and arithmetic skills. These tests are simplified versions of standard tasks and help students to demonstrate knowledge in the mentioned topics of mathematical economics. The tasks are focused only on the knowledge of basic formulas, techniques, and connections between mathematical objects, economic systems, and their elements.

Keywords: input-output model, the Monge-Kantorovich transportation problem, linear programming, nonlinear programming, the Simplex method, Lagrange multiplier, the graphic method.

JEL Classification: C180; C100; C610; C670. 


\section{INTRODUCTION}

The present article is devoted to the consideration of tests for the qualitative examination of the quality of the student knowledge in the basics of mathematical economics. The main attention is given to such sections of mathematical economics as linear programming, nonlinear programming, and an input-output model. It is noted that the main goals of studying the basics of mathematical economics by students are following:

- forming the notions of mathematical model and of modeling economic processes and phenomena;

- understanding the role of using mathematical models for economics research and obtaining scientific results;

- formatting skills for constructing mathematical models in economics, for solving economics problems by mathematical modeling.

Note that the primary basic results of studying the last-mentioned sections of mathematical economics are following: assimilating the simplex algorithm of linear programming by students including an algorithm of solving the transport problem; assimilating the basic derivation of the Leontief classical input-output model and elementary using the input-output planning method; an ability to construct mathematical models of the simplest economic problems. Peculiarities corresponding tasks (problems) in mathematical economics are cumbersome and often time-consuming time to their solving (without using a computer). Therefore, for examining the quality of students' mastering algorithms of solving the initial basic problems and for examining skills of constructing mathematical models for the simplest economic problems, it is necessary to model a system of testing tasks, in which the emphasis was placed on the knowledge and understanding of an algorithm of solving the problem, rather than calculations (performing arithmetic operations). One can use the saved time to complete additional tasks.

The presented examples of examination tests are new. These tests require less time for solving than usual tasks. One can note that in known researches in teaching econometrics, the last-mentioned problem is out in considerations.

Tests related to the following topics will be considered: constructing mathematical models, the simplex method of linear programming, the transportation problem (the Monge-Kantorovich transportation problem), the graphical method of solving linear and nonlinear programming tasks, and the Leontief classical input-output model.

\section{THEORETICAL BACKGROUND}

One can remark that in domestic researches, unfortunately, few studies have reported on errors and difficulties in studying notions of econometrics (this statement is also noted in [5]). Also, in [5], several researchers which are studied the difficulties of teaching econometrics, are noted by D. Halchenko and M. Puzyr, however, the main attention was given to researchers which investigate teaching mathematics.

The problem of the examination of knowledge in econometrics or mathematical economics is open and actual.

In foreign researches, this problem is also insufficiently explored. Here one can note the following investigations of teaching econometrics:

- general problems, modifications to the econometric curriculum or the design of an academic program in econometrics (undergraduate and graduate levels). For example, article E. Sowey [14] devoted to blended education in economics and econometrics. One can note the following researchers in this topic: J. Angrist, J. Arkes, D. Hendry, A. Kassens, G. Mizon, J.-S. Pischke [1, 2, 6, 9].

- Such researchers as E. Chinamasa, E. Kurz, V. Nhamburo, M. Sithole, E. Yoder investigate students' abilities and students' errors understudying mathematical economics in $[4,16]$. 
- Using computer technology, e-learning, or computer-based approaches in teaching econometrics or mathematical economics are considered by W. Becker, W. Greene, D. Hendry, L. Goran, Z. MacDonald, L. Miletić, and B. Nielsen [3, 7, 10, 11].

- G. Rajaram [13], studied classroom experimentation with teaching the course of econometrics with and without formative assessment.

- Teaching econometrics in different countries of the world is considered by G. Tintner [15].

\section{ReseARCH ObJective, Methodology AND DAtA}

The main goals of this paper are the following:

- to construct an example of a certain system of examination tests related to some topics in econometrics and modeling economics (mathematical economics). The focus of this aim of the research topic is to examine the basic student knowledge in topics of mathematical economics which are mentioned in the last sections of this paper. In addition, these tests require less time for solving than usual tasks in these topics.

- To simplify test tasks and to help students to demonstrate high-quality knowledge in considered areas of mathematical economics or econometrics.

The following techniques are used for obtaining results: observation, analysis of solving by students' standard and present tests, and modeling educational tasks. Also, theoretical investigations are explained by a fact that students have notable difficulties in solving standard tasks, do not have time to solve a full number of standard tasks.

\section{RESULTS AND DISCUSSION}

Let us choose some problems (tasks) considering mathematical economics. There is a certain division of the basic problem (task) into subtasks in which solving are not cumbersome and consists of checking assimilation of algorithms and methods of solving the basic initial task by students. Let us consider tests related to some basic topics of mathematical programming.

1. Using the condition of the task, construct only a mathematical model. Suppose that four types of resources are used when selling two types of goods. The total volume of each resource and the rate of cost of sales per item are listed in the table.

\begin{tabular}{|c|c|c|c|}
\hline \multirow{2}{*}{ Resources } & \multicolumn{2}{|c|}{ The rate of consumption of resources for goods of } & \multirow{2}{*}{$\begin{array}{c}\text { The total number of } \\
\text { resources }\end{array}$} \\
\cline { 2 - 3 } & the first type & the second type & 100 \\
\hline 1 & 2 & 3 & 25 \\
\hline 2 & 2 & 3 & 80 \\
\hline 3 & 4 & 5 & 250 \\
\hline 4 & 8 & 8 & \\
\hline
\end{tabular}

Tab. 1. A table to task 1.

2. Using the condition of the task, construct only an objective function. Products of four types A, $\mathrm{B}, \mathrm{C}, \mathrm{D}$ undergo sequential processing on two machines. The processing time of the unit of production of each type is shown in the table.

\begin{tabular}{|c|c|c|c|c|}
\hline \multirow{2}{*}{ Machine } & \multicolumn{4}{|c|}{ The duration of processing unit of production } \\
\cline { 2 - 5 } & A & B & C & D \\
\hline 1 & 5 & 2 & 5 & 7 \\
\hline 2 & 1 & 2 & 2 & 1 \\
\hline
\end{tabular}

Tab. 2. A table to task 2. 
The cost of producing a unit of production of each type is defined as quantities directly proportional to the time the machines are used. The cost of one work hour is 100 EURO for machine 1 and 200 EURO for machine 2. The duration of using a machine is limited: for machine 1, it is 500 hours, and for machine 2, it is 400 hours. The unit price of production A, B, C, D is 1000, 1200, 1800 and 2000 EURO respectively. Determine the optimal production plan that maximizes total profit.

The last-mentioned tests are without variants of answers. This fact complicates these tasks, but for students, it is impossible to guess the answers by the conditions of the tasks.

Now one can begin with tests related to the simplex method of linear programming.

Suppose that a mathematical model is of the form:

$$
\begin{aligned}
& z=3 x_{1}+6 x_{2}+2 x_{3}+3 x_{4} \rightarrow \max \\
& \left\{\begin{array}{l}
3 x_{1}+3 x_{2}+3 x_{3}+4 x_{4} \leq 600 \\
5 x_{1}+2 x_{2}+2 x_{3}+5 x_{4} \leq 500 .
\end{array}\right.
\end{aligned}
$$

\begin{tabular}{|c|c|c|c|c|c|c|c|c|c|}
\hline \multirow{2}{*}{$\begin{array}{c}\text { Table } \\
\text { No. }\end{array}$} & \multirow{2}{*}{$\begin{array}{c}\text { Row } \\
\text { No. }\end{array}$} & \multirow[b]{2}{*}{ Base } & \multirow{2}{*}{$\begin{array}{c}\text { The } \\
\text { reference } \\
\text { plan }\end{array}$} & \multicolumn{6}{|c|}{ Coefficients for variables } \\
\hline & & & & $x_{1}$ & $x_{2}$ & $x_{3}$ & $x_{4}$ & $x_{5}$ & $\cdots$ \\
\hline \multirow{3}{*}{1} & 0 & $\mathrm{z}$ & 0 & -3 & -6 & -2 & -3 & $\cdots$ & $\cdots$ \\
\hline & 1 & variable1 $=\ldots$ & $\ldots$ & 3 & 3 & 3 & 4 & $\cdots$ & $\cdots$ \\
\hline & 2 & variable $2=\ldots$ & $\ldots$ & 5 & 2 & 2 & 5 & $\cdots$ & $\cdots$ \\
\hline
\end{tabular}

Completing the following simplex table (using new variables if necessary), answer the questions:

Tab. 3. Simplex table 1.

1. Specify the base variables: (variable 1 , variable 2$)=$

2. Write the vector of the initial reference plan:

3. Is this plan optimal?

4. What variable should be deduced from the basis?

5. What variable should be introduced into the basis?

6. Write a vector column whose elements are the numbers in simplex table 2 in the place of the key column of simplex table 1 :

Let us remark that one of the simplest techniques of the simplex method was described in [8]. In the present paper, this technique is used. Really, in the simplex table, potentials are not calculated. Instead of, an objective function is used, i.e., one can write $z=3 x_{1}+6 x_{2}+2 x_{3}+3 x_{4}$ as $z-3 x_{1}-6 x_{2}-2 x_{3}-3 x_{4}=0$.

In the simplex table, the objective function is in the last-mentioned form. A variable for which the minimum negative coefficient corresponds in row 0 , is introduced into the basis.

Now let us consider tasks corresponding to the transportation problem (the Monge-Kantorovich transportation problem). 
Using the following transportation table, answer the questions:

\begin{tabular}{|c|c|c|c|c|c|}
\hline \multirow{2}{*}{ Manufacturers $A_{i}$} & \multicolumn{4}{|c|}{ Customers $B_{j}$} & \multirow{2}{*}{$\begin{array}{c}\text { Potentials, } \\
u_{i}\end{array}$} \\
\hline & $b_{1}=100$ & $b_{2}=50$ & $b_{3}=80$ & $b_{4}=70$ & \\
\hline$a_{1}=200$ & $\begin{array}{c}2 \\
100\end{array}$ & $\begin{array}{c}2 \\
20\end{array}$ & $\begin{array}{c}1 \\
80\end{array}$ & 4 & $u_{1}=$ \\
\hline$a_{2}=20$ & 3 & $\begin{array}{c}1 \\
20\end{array}$ & 4 & 3 & $u_{2}=$ \\
\hline$a_{3}=80$ & 2 & $\begin{array}{c}3 \\
10\end{array}$ & 3 & $\begin{array}{c}2 \\
70\end{array}$ & $u_{3}=$ \\
\hline Potentials, $v_{j}$ & $v_{1}=0$ & $v_{2}=$ & $v_{3}=$ & $v_{4}=$ & \\
\hline
\end{tabular}

Tab. 4. The transportation table.

1. Find the sum of all potentials under the condition $v_{1}=0: \sum_{i=1}^{3} u_{i}+\sum_{j=1}^{4} v_{j}=$

2. Is the reference plan degenerated?

3. Is the reference plan optimal?

4. If the reference plan is not optimal, indicate the cell (s) for which the optimality condition is not fulfilled.

5. Specify the cycle under construction to move to the new optimal plan.

6. Write a new optimal plan in the matrix form.

Note that one can begin the last series of tests with a task in which the transportation table has not 6 but 5 filled cells, i.e., the reference plan is degenerate (then it is needed to give a test on possible variants of filling one of the empty cells in the table), or with the task in which the transportation problem is open.

Let us consider variants of tests on the graphical method of solving linear and nonlinear programming tasks.

1. Solve the following optimization problem graphically:

$$
\begin{aligned}
& z=x+2 y \rightarrow \max \\
& \left\{\begin{array}{c}
y \leq 7-x \\
x \leq 4 \\
y \leq 6 \\
x \geq 0, y \geq 0 .
\end{array}\right.
\end{aligned}
$$

Using the obtained results, indicate:

1.A. Coordinates of the normal vector are:

1.B. The maximum value of the objective function (when this value exists) is:

1.C. A point of the maximum value of the objective function (when this point exists) is:

2. Find the maximum and minimum points (if there are) of the function $z=(x-1)^{2}+(y-1)^{2}$ 
under the conditions

$$
\left\{\begin{array}{c}
x+y \leq 2 \\
x \geq 1 \\
y \leq 2 \\
x \geq 0, y \geq 0 .
\end{array}\right.
$$

Then:

2A. A point of the maximum of this function is:

2B. A point of the minimum of this function is:

Let us describe tests related to the method of Lagrange multipliers in mathematical optimization.

1. Write the Lagrange function for the task

$$
f=2\left(x_{1}^{2}-3 x_{1}+5\right) x_{1}+3 x_{2}\left(x_{2}^{2}+2 x_{2}+1\right)
$$

under the conditions

$$
\left\{\begin{array}{c}
x_{1}+x_{2}=7 \\
x_{1} \geq 0, x_{2} \geq 0
\end{array}\right.
$$

2. Suppose that we obtain the Lagrange function of the following form under solving a certain problem of nonlinear programming:

$$
L\left(x_{1}, x_{2}, \lambda_{1}\right)=-x_{1}^{3}+x_{1}^{2}-x_{2}^{3}+\lambda_{1}\left(5-x_{1}-x_{2}\right)
$$

Task:

A. Write the corresponding Hessian matrix.

B. Find the optimums, if they exist.

The following series of tests are devoted to the Leontief classical input-output model. Models of intersectional balance. Suppose we have an economy with two sectors.

1. Find values $x_{1}^{*}$ and $x_{2}^{*}$ of gross output of the industries at the given sectors of the final output in the planning period, if the matrix of coefficients of full material costs $C=\left(\begin{array}{ll}0,2 & 0,1 \\ 0,5 & 1,4\end{array}\right)$ and the vector of finished products $\vec{y}^{*}=\left(\begin{array}{l}20 \\ 30\end{array}\right)$ in the planned period are specified.

Answer: $\vec{x}^{*}=\left(\begin{array}{c}x_{1}^{*} \\ x_{2}^{*}\end{array}\right)=$

2. Find the intersectional product flows in the planned period if the matrix of direct material costs $A=\left(\begin{array}{ll}0,1 & 0,2 \\ 0,5 & 0,5\end{array}\right)$ and the vector $\vec{x}^{*}=\left(\begin{array}{l}200 \\ 100\end{array}\right)$ are given .

Answer: $X^{*}=\left(\begin{array}{ll}x_{11}^{*} & x_{12}^{*} \\ x_{21}^{*} & x_{22}^{*}\end{array}\right)=$ 
3. Find net products for both industries during the planning period whenever $\vec{x}^{*}=\left(\begin{array}{l}100 \\ 200\end{array}\right)$ and $X^{*}=\left(\begin{array}{cc}20 & 5,5 \\ 7,2 & 6\end{array}\right)$

4. Find coefficients $t_{1}$ and $t_{2}$ of the direct labor by the data from the table

\begin{tabular}{|c|c|c|}
\hline \multirow{2}{*}{ Name of coefficients } & \multicolumn{2}{|c|}{ Consumer industry } \\
\cline { 2 - 3 } & $\mathbf{1}$ & $\mathbf{2}$ \\
\hline Gross production & 100 & 150 \\
\hline Labor costs & 90 & 160 \\
\hline The cost of production assets & 110 & 80 \\
\hline
\end{tabular}

Tab. 5. A table to task 4.

Answer: $\vec{t}=\left(t_{1} ; t_{2}\right)=$

5. Using the last table and the matrix $C=\left(\begin{array}{cc}0,2 & 0,1 \\ 0,5 & 1,4\end{array}\right)$ of coefficients of full material costs, find coefficients $T_{1}$ and $T_{2}$ of the full labor. Answer: $\vec{T}=\left(T_{1} ; T_{2}\right)=$

6. Using the last table, calculate coefficients $f_{1}$ and $f_{2}$ of the direct capital intensity.

7. Using results of the previous task and the matrix $C=\left(\begin{array}{cc}0,2 & 0,1 \\ 0,5 & 1,4\end{array}\right)$ of coefficients of full material costs, find coefficients $F_{1}$ and $F_{2}$ of the full capital intensity.

8. Find the labor resources for output of all two industries in the planning period whenever coefficients $t_{1}$ and $t_{2}$ of the direct labor are $\vec{t}=(0,8 ; 1,5)$ and the gross output of industries in the planned period are $\vec{x}^{*}=\left(\begin{array}{l}110 \\ 105\end{array}\right)$.

9. Using the coefficients $f=\left(\begin{array}{ll}1,5 & 0,7\end{array}\right)$ of the direct capital intensity and $\vec{x}^{*}=\left(\begin{array}{l}110 \\ 105\end{array}\right)$, find the main production assets $\Phi_{1}^{*}$ and $\Phi_{2}^{*}$ in the planning period.

10. Find coefficients of the direct material cost by information from the table

\begin{tabular}{|c|c|c|}
\hline \multirow{2}{*}{ Manufacturing industry } & \multicolumn{2}{|c|}{ Consumer industry } \\
\cline { 2 - 3 } & $\mathbf{1}$ & $\mathbf{2}$ \\
\hline 1 & 10 & 25 \\
\hline 2 & 50 & 20 \\
\hline Pure production & 40 & 155 \\
\hline Gross production & 100 & 200 \\
\hline
\end{tabular}

Tab. 6. A table to task 10. 
Answer: $A=\left(\begin{array}{ll}a_{11} & a_{12} \\ a_{21} & a_{22}\end{array}\right)=$

Let us note that the last series of tests aimed at testing the knowledge of basic relationships (formulas) and not at arithmetic operations.

Finally, from separately considered problems, it follows that it is useful to focus the attention of students on the specific sections of pure mathematics that are used in studying correspondent topics of economic mathematics.

\section{CONCLUSIONS}

In the present paper, for quality testing students' knowledge in some topics of mathematical economics, a certain system of examples of tests was modelled and is considered. The main attention was given to tests from the following topics: constructing mathematical models of linear programming, the input-output model, the Monge-Kantorovich transportation problem, the simplex method of linear programming, the graphic method of linear and nonlinear programming, the method of Lagrange multipliers in mathematical optimization. One can remark that his problem is insufficiently explored in foreign and domestic researches.

Tests presented in this paper require less time for solving than usual tasks and do not focus on the repetition of auxiliary mathematical knowledge and arithmetic skills. The described tasks are focused only on the knowledge of basic formulas, techniques, and connections between mathematical objects, economic systems, and their elements. These tests are simplified versions of standard tasks and help students to demonstrate knowledge in the mentioned topics of mathematical economics.

\section{REFERENCES}

[1] Angrist J.D., Pischke J.S. Undergraduate Econometrics Instruction: Through Our Classes, Darkly. Journal of Economic Perspectives, 31 (2) (2017), 125-144. doi: 10.1257/jep.31.2.125

[2] Arkes J. Teaching Graduate (and Undergraduate) Econometrics: Some Sensible Shifts to Improve Efficiency, Effectiveness, and Usefulness. Econometrics, 8 (3) (2020).doi:10.3390/econometrics8030036

[3] Becker W.E., Greene W.H. Teaching Statistics and Econometrics to Undergraduates. Journal of Economic Perspectives, 15 (4 ) (2001), 169-182. doi: 10.1257/jep.15.4.169

[4] Chinamasa, E., Nhamburo, V., Sithole, M. Analysis of students' errors on linear programming at secondary school level: implications for instruction. Zimbabwe Journal of Educational Research, 26 (1) (2014), 54-73. Available at: https://opendocs.ids.ac.uk/opendocs/handle/20.500.12413/10232?show=full

[5] Halchenko D., Puzyr M. About errors and difficulties mathematical statistical and econometrical concepts. Bulletin of the Cherkasy Bohdan Khmelnytsky National University.Series "Pedagogical Sciences", 12 (2017), 18-26. (in Ukrainian)

[6] Hendry D.F., Mizon G. E. Improving the teaching of econometrics. Cogent Economics \& Finance, 4 (1) (2016). doi: 10.1080/23322039.2016.1170096

[7] Hendry D.F., Nielsen B. A. Modern Approach to Teaching Econometrics. European Journal of Pure and Applied Mathematics, 3 (3) (2010), 347-369. Available at: https://www.ejpam.com/index.php/ejpam/article/view/796

[8] Ivashchuk O.T. Economical and Mathematical Modeling. Tutorial, TNEU "Economichna Dumka", Ternopil, 2008. (in Ukrainian)

[9] Kassens A.L. Theory vs. practice: Teaching undergraduate Econometrics. The Journal of Economic Education, 50 (4) (2019). 367-370. doi: 10.1080/00220485.2019.1654958 
[10] MacDonald Z. Teaching Linear Programming using Microsoft Excel Solver. Computers in Higher Education Economics Review (CHEER), 9, (3) (1995), Available at: https://www.economicsnetwork.ac.uk/cheer/ch9_3/ch9_3p07.htm

[11] Miletić L., Goran L. Research and evaluation of the effectiveness of e-learning in the case of linear programming. Croatian Operational Research Review, 7 (1) (2016), 109-127.

[12] Nakonechnyi S.I., Savina S.S. Mathematical programming, Tutorial, KNEU, Kyiv, 2003. (in Ukrainian)

[13] Rajaram G. Teaching Econometrics Using Formative Assessment. Journal for Economic Educators, 11 (1) (2011), 1-12.

[14] Sowey E.R. University teaching of econometrics a personal view. Econometric Reviews, 2 (2) (1983), 255289.doi: 10.1080/07311768308800046

[15] Tintner G. The Teaching of Econometrics. Econometrica, 22, (1) (1954), 77-100. Available at: http://www.jstor.org/stable/1909835

[16] Yoder S. Elizabeth, Kurz M. Elizabeth. Linear Programming Across the Curriculum. Journal of Education for Business, 90 (1) (2015), 18-23, doi: 10.1080/08832323.2014.968516

Address: Symon Serbenyuk, Higher Professional College of Lviv State University of Life Safety, 7, General Arabey Str., Vinnytsia, 21000, Ukraine.

E-mail: simon6@ukr.net.

Received: January 11, 2021; revised: June 14, 2021.

Сербенюк Симон. Про деякі аспекти екзаменування в економетриці. Журнал Прикарпатського університету імені Василя Стефаника, 8 (3) (2021), 7-16.

Викдадання економетрики вивчалося рядом дослідників, однак досліджень про якість екзаменування та спрощення тестів для демонстрації якісних знань студентами 3 конкретних тем економетрики чи математичної економіки недостатньо.

Визначено такі основні цілі вивчення студентами основ математичної економіки чи економетрики: формування понять математичної моделі та моделювання економічних процесів та явищ; розуміння ролі використання математичних модедей для економічних досліджень та отримання наукових результатів; навички форматування для побудови математичних моделей в економіці 3 метою вирішення економічних задач за допомогою математичного моделювання.

Головною метою даної статті є пошук шляхів спрощення тестових завдань, допомога студентам у демонстрації якісних знань в певних областях математичної економіки, а також побудова системи тестових завдань, у якій акцент робиться на знання та розуміння алгоритму розв' язування проблеми.

У даній статті для якісної оцінки знань студента з основ математичної економіки була побудована і розгдядається певна система тестів. Основна увага також приділяється алгоритмам та прийомам вирішення деяких завдань (задач) математичної економіки. Розгдядаються наступні теми математичної економіки: побудова математичних моделей дінійного програмування, модель "витрати-випуск", транспортна задача Монжа-Канторовича, симплексний метод дінійного програмування, графічний метод лінійного та нелінійного програмування, метод множників Лагранжа у математичній оптимізації. Відзначено деякі основні результати вивчення лінійного програмування, нелінійного програмування та моделі "витрати-випуск".

Змодельовано нову систему тестів, яка відповідає меті даної статті. Описані тести вимагають менше часу для розв' язування ніж звичайні завдання. Тут відсутній акцент на повторення допоміжних математичних знань та арифметичних навичок. Наведені тести є спрощеними версіями стандартних завдань і допомагають студентам продемонструвати знання у згаданих темах математичної 
економіки. Завдання зосереджені дише на знанні основних формул, методів та зв'язків між математичними об'єктами, економічними системами та їх елементами.

Кдючові слова: модель "витрати-випуск", транспортна задача Монжа-Канторовича, дінійне програмування, нелінійне програмування, симплексний метод, множник Аагранжа, графічний метод. 